\title{
GAMIFICATION IN FOR-PROFIT ORGANISATIONS: A MAPPING STUDY
}

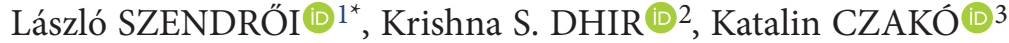 \\ ${ }^{1,2}$ Doctoral School of Regional Sciences and Business Administration \& Management Sciences, \\ Széchenyi István University, Györ, Hungary \\ ${ }^{3}$ Department of International and Theoretical Economics, Széchenyi István University, Györ, Hungary
}

Received 4 January 2020; accepted 23 June 2020

\begin{abstract}
This study reviews prevailing trends in "for-profit" business-related gamification. It examines the current literature, focusing on gamification elements, industries and variables that is of interest to researchers in different business environments. A systematic mapping approach was applied to this study. Articles were selected from different databases in a two-step screening process, subject to sets of inclusion and exclusion criteria. A total of 25 articles were further for: (1) represented industries, (2) orientation of the gamified system, (3) types of implementation, (4) gamification elements analysed, (5) impact on companies, and (6) company variables analysed. Results confirmed that the number of empirical studies on gamification in for-profit organisations is growing. Researchers have placed greater emphasis on analysing customer-related gamification environments than on employee-oriented gamification. This finding is consistent with the prevailing trend of increasing demand from practitioners to gamify customer-related processes. This is likely due to the potential for higher positive impact on the performance of companies. Most frequently deployed gamification elements are badges, rewards, and leader boards. The literature suggests that over all, gamification has a positive effect on various company variables, such as motivation, engagement of employees, brand loyalty, and customer experience. This paper highlights the particular areas of business-related gamification that have already been examined and possible future directions.
\end{abstract}

Keywords: gamification, organisations, customer environment, engagement, motivation, mapping study, badges, levels, points.

\section{JEL Classification: $M$.}

\section{Introduction}

Gamification is a relatively new research area. Nevertheless, it is already being applied to various disciplines. There are numerous studies that focus on the educational context of gamification (Adukaite et al., 2017; Fisher et al., 2014; Martí-Parreño et al., 2016). Additionally, the concept of gamification, with its tools and elements, is being applied to many other areas as well, including business (Deterding et al., 2011; Stanculescu et al., 2016; Rauch, 2013; Herzig, 2012; Routledge, 2016). Gamification gained popularity after it was recognized that elements adopted from real games could increase engagement and motivation of stakeholders in several areas. There may be a number of reasons for adopting gamification in organisations, depending on various gamified environments. Companies may focus on gamifying the processes of their customers to gain higher loyalty toward their brands and products or enhancing the motivation and engagement of the customers (Kim \& Ahn, 2017). Organisations may also seek to increase the performance of their employees with the implementation of gamification elements in the working environment (García et al., 2017), ERP systems (Suh et al., 2017) or in employee training (Alcivar \& Abad, 2016).

The purpose of this study is to review and describe the recent trends in business related gamification. Basic assumption of authors is that literature base of gamification can give illustrative picture of trends in practice. A mapping study methodology is used to gather articles on the topic of gamification and provide a summary of the applications in different areas. Mapping studies on gamification are available in the context of education (Dicheva et al., 2015; de Sousa Borges et al., 2014). Our study focusses on for-profit businesses to provide a basis for future research and to show which elements have been used in various industries and which variables have been analysed in prior studies. The research questions in this study are

*Corresponding author. E-mail: szendroi.laszlo@sze.hu 
the following: (Q1) In which industries is gamification applied? (Q2) What is the orientation of the application: Is gamification related to the customer environment or the employee environment in previous studies? (Q3) Which forms of implementing gamification were analysed by former studies? (Q4) What type of gamification elements are deployed by the researchers in previous studies? (Q5) In prior studies, how gamification affected the outputs of the companies' operation? (Q6) What are the variables that are likely to be enhanced through gamification when organisations implement it?

In Section 1, we provide a literature review of gamification. Subsequently, the possible use of gamification in different areas is discussed, along with possible gamification elements that may be used when designing a gamified environment. In Section 2, the methodology of this study is presented. In Section 3, our findings with respect to different industries, gamification elements, and type of implementation, are discussed.

\section{Literature review}

Terrill (2008) was the first to suggest "taking game mechanics and applying them to other web properties to increase engagement." The most common definition accepted by many researchers comes from Deterding et al. (2011). He defined gamification as the use of video-game elements in the context of non-gaming systems to improve user engagement and experience. There are also other definitions to describe gamification. It can be defined as the process of using game thinking and mechanics to engage users (Roth et al., 2015). Gartner Study (2012) used a more complex definition: "The use of game mechanics and game design techniques in nongame contexts to design behaviours, develop skills or to engage people in innovation." Bunchball (2010) defined gamification from the business perspective, as follows: "gamification is the process of integrating game dynamics (and game mechanics) into a website, business service, online community, content portal, or marketing campaign in order to drive participation and engagement." Oxford dictionary describes gamification as: "The application of typical elements of game playing (e.g. point scoring, competition with others, rules of play) to other areas of activity, typically as an online marketing technique to encourage engagement with a product or service." (lexico, n.d.)

\subsection{Gamification in different areas}

The growing literature on gamification covers a wide range of areas, including innovation management (Roth et al., 2015), human resource management (Dale, 2014), sustainability promotion (Morford et al., 2014; Huber \& Hilty, 2015; Kim, 2015), and local regional development (Fekete, 2018). Other specific areas are also examined by many authors, such as the establishment of surveys (Sillaots, 2014), the improvement of vegetable intake for young adults (Nour et al., 2018), alcohol interventions for college students (Boyle et al., 2017, standing in public transportation (Kuramoto et al., 2013) or gamified application for learner drivers (Fitz-Walter et al., 2017). A large number of gamification articles are written in the context of improving education (Buckley \& Doyle, 2017; Eynard et al., 2017; Yildirim, 2017). Many companies have recognised that gamification can make a positive impact on their business, so the examination of gamification related to for-profit organisations is also popular (Alcivar \& Abad, 2016; Hamari, 2017; Landers et al., 2017). Mora et al. (2017) have provided a systematic literature review on gamification design. They conclude that the majority of design frameworks of gamification is written in a business context with far fewer concerning generic, learning and health frameworks. The growing number of articles show that there exists a major potential to change several non-game environments in the future. Market research published by Technavio has estimated that the value of the global gamification market will exceed $\$ 6$ billion by 2019 (Businesswire, n.d.), suggesting that it holds huge business potential for developers of these systems.

\subsection{Gamification elements}

Hamari et al. (2014) found that the most common motivational terms related to gamification were points, leader boards, achievements/badges, levels, story/theme, clear goals, feedback, rewards, progress, and challenge. Dicheva et al. (2015) found that the following gamification elements are the most commonly used in an educational context: points, badges, leaderboards, levels, virtual currency, progress bars, and avatars. These elements have different motivational values; therefore, they have to be customised according to the environment and different types of individuals (Barata et al., 2015). It is difficult to define each gamification element as in many cases they are related to each other. At times, researchers define gamification differently (Costa et al., 2017).

There are different approaches to operationalise the gamification elements. One of the most commonly used approach is based on the Octalysis framework designed by Chou (2015), in which gamification is dictated by a set of drivers. Another recent model is the Gamification Model Canvas developed by Jiménez and Escribano (2015). They were inspired by the business model canvas (Osterwalder \& Pigneur, 2003), in which one side represents the designer and efficiency and the other side the player and value. Bharati et al. (2016) applied a Sequential Minimal Optimization algorithm to arrange 60 different gaming applications in decreasing order of impact. From these, they identify 24 game features to discern that of them, 15 were shared by the successful applications. They based their study only on the presence of the game features, not on the manner of their use. In another study, Kappen and Nacke (2013, pp. 3-4) created guidelines for effective gamification. 


\subsection{Gamification in businesses}

In the recent years, business professionals have recognized that using gamification holds strong potential for positive outcomes. For this reason, research on this phenomenon is increasing, Companies in different industries are implementing gamified systems to support their respective business goals. Companies appear to have two main motivations: The first is to increase the engagement through increased loyalty and motivation of customers. The second is to enhance the engagement of the employees in their work environment and, correspondingly, increase their job satisfaction.

To increase employee engagement, Ergle (2016) proposes the following eight steps to build an effective business game:

1. Identify the overall business goal to which the top management aspires; 2 . Identify the main objective of gamification. This will help identify the functions to be gamified; 3. Identify the users, answering such questions as: what is in it for them? What motivates them to engage? What is their interest?; 4. Identify the context or culture in which the game will be used; 5 . Design the game and its mechanics: select game elements that engage a user while accomplishing the business goal; 6 . Create the metrics to determine effectiveness, e.g., ROI; 7. Implement and communicate the plan; 8. Continually monitor the effectiveness and added value of the game, while adjusting and improving the gamification experience through ongoing feedback.

It is also important to consider the efforts needed from the members of the gamification project. García et al. (2017) recognized and measured such efforts. They assumed that different levels of efforts are needed in different steps of the project. The steps are: objective, definition, player analyses, scope definition and feasibility, analyses and design, and development. Development of the gamification project requires the most hours from the project team and the researchers while analyses and design were the second most time-consuming step.

There are game versions of science-based behavioural assessments, and data science tools to help companies search for appropriate applicants. The benefits of such tools are twofold: Firstly, this kind of tool can evaluate applicant behaviour from different perspectives. Secondly, with immediate feedback, it makes the recruitment processes of the companies efficient, reducing the investment of time (Narayanan et al., 2016).

Workplace motivation can also be enhanced with different gamified systems. However, it has to be carefully designed so as not to have a negative effect. This means that analyses of the behaviour of employees and their attitudes toward gamified processes should be carefully considered using the most appropriate design (Perryer et al., 2016).

Robson et al. (2016) assert that player types matter. They identified four different player types that require different kinds of gamification. Personalities vary and understanding this variability is necessary for creating engaging experiences.
There is a wide range of gamification elements available for designers, but the literature focuses on just a few of them. Badges, leader boards, points and rewards are the most popular components to gamify a non-game environment. As stated before, our study focusses on gamification in for-profit organisations. In such organisations, gamification is being applied, not only in marketing contexts but also in human resources, where the influence on employee behaviour, especially regarding their knowledge, is of interest. Werbach and Hunter (2012, p. 82) proposed a classification of game elements as: (1) "Dynamics - are the big-picture, aspects of the gamified systems that you have to consider and manage but which you never directly enter into the game" (2) "Mechanics - are the basic processes that drive the action forward and generate player engagement" (3) "Components - are the specific instantiations of mechanics or dynamics". By focusing on these three classifications, designers can develop a better range of useful elements. Costa et al. (2017) also classified game elements into certain dimensions and collected the different definitions according to the literature. Based on this the dimensions of Werbach and Hunter (2012) were expanded with game elements, game principles, and game aesthetics. It is also important to differentiate between games, serious games and gamification because they have different purposes.

\section{Research approach}

The high number of articles related to this topic justified using a mapping research methodology to reveal the key areas of application. It is essential to recognize those areas that have not yet been investigated, or where the research has been inadequate. A mapping of the literature was conducted to evaluate the prevailing trends in the literature.

A mapping study has several benefits for researchers. After a thorough mapping study, it is easier and less timeconsuming to identify areas requiring attention. Such a study also aids construction of relevant research questions. Besides the procedures, forms, and experiences can also be reused, and past findings can provide a basis for comparison with the follow-up revelations. Finally, the primary studies provided can be used to validate further research and results (Kitchenham et al., 2011).

Our mapping study was conducted in accordance to the systematic steps specified by Petersen et al. (2008). We implemented their five-step process, including (i) Definition of the research question, (ii) Conduct the search, (iii) Screening of papers, (iv) Keywording using abstracts, (v) Data extraction and mapping process, shown in Figure 1.

The next step was the identification of primary studies. To identify these, we searched high quality databases. The following search engines were used to collect the articles: EBSCO, Science Direct, and Springer Link. We used the term, "gamification", to search for the articles of interest. The term was searched among the titles, abstracts, and 


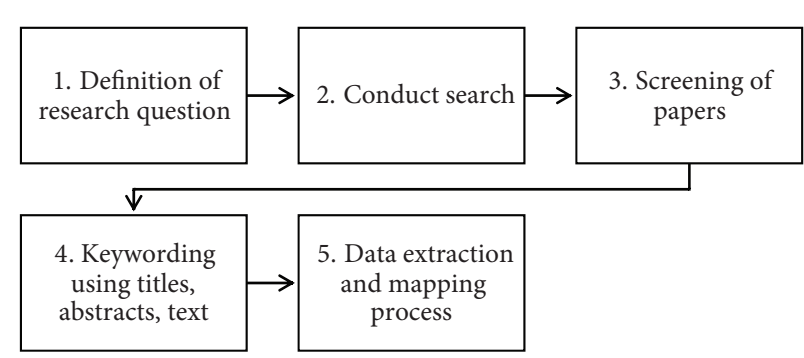

Figure 1 . The systematic mapping process (own source based on: Petersen et al., 2008)

keywords from the chosen search databases. Only English language academic journals were searched. A total of 639 articles were thus obtained After checking for and screening out the duplicates, 575 articles were available for further analyses. The allocation of the articles by year can be seen in Figure 2, which shows the growing popularity of gamification among researchers.

The next step in the research process was to select the appropriate primary studies from the collected articles, for further analyses. For this purpose, a set of inclusion and exclusion criteria was prepared.

The inclusion criteria were the following:

- Where several papers reported the same study, only the most complete one is included.

- Studies that answer at least one research question is included.

To avoid overlaps between the studies it is important not to include all the articles that provide the same results. Only the most complete study was selected for the analysis. Also, only those articles were included in the study that answered at least one research question.

The exclusion criteria consisted of the following:

- Studies that are not written in English is excluded.

- Studies that do not contain empirical research is excluded.

- The study is not related to gamification in for-profit organizations is excluded.
The studies had to have contained an analysis of gamification among for-profit companies, else they were excluded. For instance, if a study investigated only the behaviour of users in games in general, or the purpose of the implementation of gamification did not contain for-profit goals, they were excluded. Articles that were written in an educational context were also excluded, except if they examined the training or learning environment for employees or customers of a for-profit organisation.

After the application of the inclusion and exclusion criteria, a final set of 41 articles was obtained. The articles in this set were subjected to further analyses. The number of articles during each phase of the research can be seen in Table 1.

Table 1. The number of articles in each phase of the research process

\begin{tabular}{|l|c|}
\hline Total number of articles & 544 \\
\hline After checking duplicates & 535 \\
\hline After the first screening & 112 \\
\hline Final selection & 41 \\
\hline
\end{tabular}

\section{Evaluation and results}

In this section, we present the results of our analysis through 8 subtopics, including number of studies by year, outlets, industry, orientation, types of implementation, gamification elements, effects on companies, and examined variables. In each of these subtopics, a data analysis and overview of the trends is discussed below.

\subsection{Number of selected papers by year}

In Figure 3, we can see the presence of an increasing trend of rate of investigations. One difference between the two Figures, Figure 2 and Figure 3, should be clarified. In Figure 2 we see articles that all appeared in academic journals. However, in Figure 3, we see only those articles that

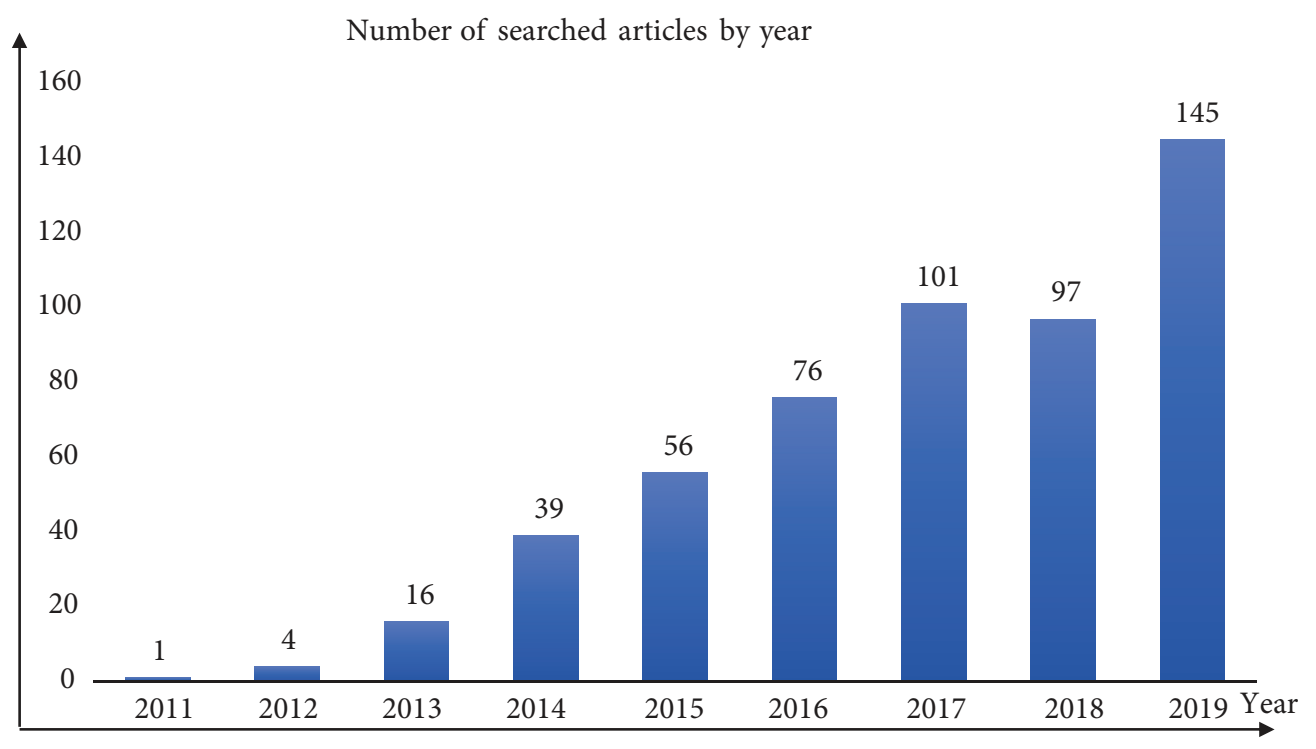

Figure 2. The distribution of the collected articles from search databases by year after checking duplicates 


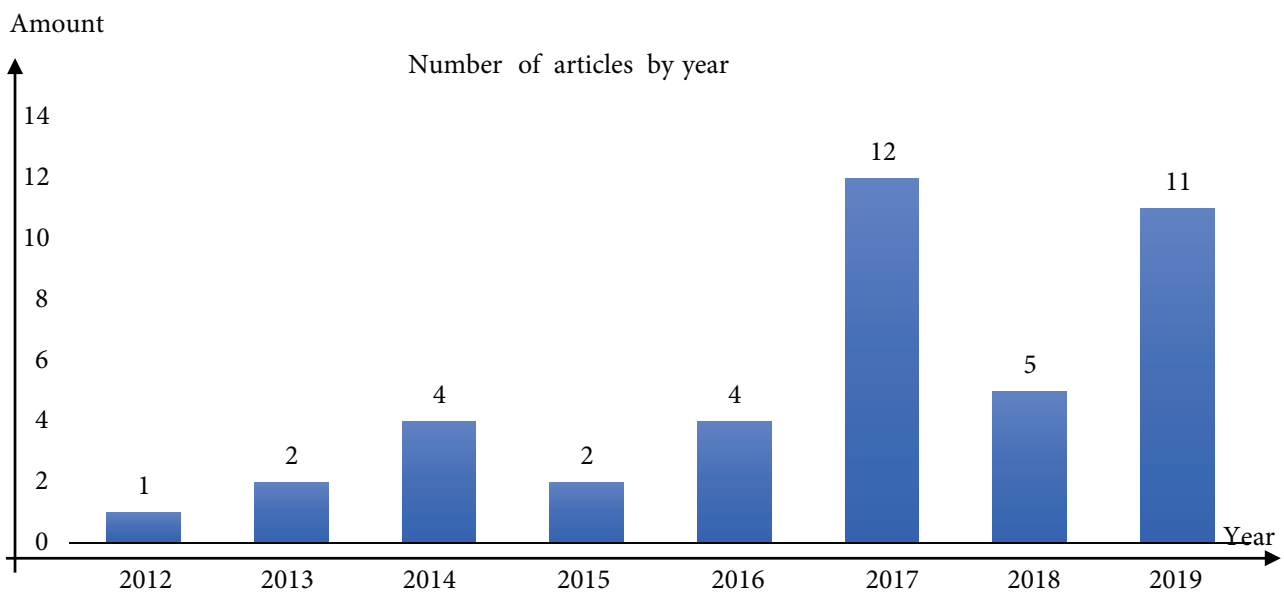

Figure 3. The distribution of the final selection of articles by year

were based on empirical study. The difference between the two could explain the evolution of the research of gamification. Since 2011, when the first definitions of gamification emerged, most articles written were theory-based, where the goal was mainly to set up a framework to support further research. Comparing the results with another mapping study provided by Dicheva et al. (2015), which contained empirical studies albeit in educational contexts, we can see a growing number of research, even though their collection was executed by 2014 .

\subsection{Number of studies by Journal}

Most of the business-related gamification articles that were examined in this study were published in Computers in Human Behaviour. It consists of a total number of 10 papers. The remaining 31 papers were widely dispersed among 26 different jourrnals. This distribution demonstrates that gamification covers a wide range of business interests and disciplines. This variety is evident in Table 2.

Table 2. Journals and the articles published in them on the topic of business-related gamification

\begin{tabular}{|l|l|}
\hline \multicolumn{1}{|c|}{ Journal } & \multicolumn{1}{c|}{ Articles } \\
\hline $\begin{array}{l}\text { Computers in Human } \\
\text { Behaviour }\end{array}$ & $\begin{array}{l}\text { Alcivar and Abad (2016) } \\
\text { Feng et al. (2018) } \\
\text { Hamari (2017) } \\
\text { Hsu \& Chen (2018b) } \\
\text { Landers et al. (2017) } \\
\text { Li (2017) } \\
\text { Rodrigues et al. (2016a) } \\
\text { Rodrigues et al. (2016b) } \\
\text { Rodrigues et al. (2016c) } \\
\text { Yang et al. (2017) }\end{array}$ \\
\hline $\begin{array}{l}\text { International Journal of } \\
\text { Information Management }\end{array}$ & $\begin{array}{l}\text { Köse et al. (2019) } \\
\text { Moro et al. (2019) } \\
\text { Xi \& Hamari (2019) }\end{array}$ \\
\hline $\begin{array}{l}\text { Journal of Retailing and } \\
\text { Consumer Services }\end{array}$ & $\begin{array}{l}\text { Högberg et al. (2019a) } \\
\text { Högberg et al. (2019b) }\end{array}$ \\
\hline $\begin{array}{l}\text { Technological Forecasting } \\
\text { and Social Change }\end{array}$ & $\begin{array}{l}\text { Hsu and Chen (2018a) } \\
\text { Poncin et al. (2017) }\end{array}$ \\
\hline $\begin{array}{l}\text { Journal of Interactive } \\
\text { Marketing }\end{array}$ & $\begin{array}{l}\text { Kim and Ahn (Grace) (2017) } \\
\text { Leclercq et al. (2018) }\end{array}$ \\
\hline
\end{tabular}

End of Table 2

\begin{tabular}{|c|c|}
\hline Journal & Articles \\
\hline $\begin{array}{l}\text { International Journal of } \\
\text { Market Research }\end{array}$ & Bailey et al. (2015) \\
\hline $\begin{array}{l}\text { Journal of Forensic } \\
\text { Accounting Research }\end{array}$ & Baxter et al. (2017) \\
\hline $\begin{array}{l}\text { Journal of Information } \\
\text { Systems }\end{array}$ & Baxter et al. (2016) \\
\hline SpringerPlus & Conaway and Garay (2014) \\
\hline Information and Management & Dissanayake et al. (2019) \\
\hline $\begin{array}{l}\text { International Journal of } \\
\text { Research in Marketing }\end{array}$ & Eisingerich et al. (2019) \\
\hline Procedia Computer Science & Fernandes et al. (2012) \\
\hline $\begin{array}{l}\text { Journal of Systems and } \\
\text { Software }\end{array}$ & García et al. (2017) \\
\hline $\begin{array}{l}\text { Electronic Commerce } \\
\text { Research and Applications }\end{array}$ & Hamari (2013) \\
\hline Telematics and Informatics & Hsu et al. (2017) \\
\hline $\begin{array}{l}\text { Information Technology and } \\
\text { People }\end{array}$ & Huang et al. (2019) \\
\hline Journal of Business Research & Jang et al. (2018) \\
\hline Procedia CIRP & Kampker et al. (2014) \\
\hline Information Systems & $\begin{array}{l}\text { Leszczyński and Zakrzewicz } \\
(2019)\end{array}$ \\
\hline Tourism Management & Liang et al. (2017) \\
\hline $\begin{array}{l}\text { IFIP Advances in Information } \\
\text { and Communication } \\
\text { Technology }\end{array}$ & Lounis et al. (2013) \\
\hline $\begin{array}{l}\text { Procedia - Social and } \\
\text { Behavioral Sciences }\end{array}$ & Lucassen and Jansen (2014) \\
\hline Computers and Education & Park et al. (2019) \\
\hline Electronic Markets & Sigala (2015) \\
\hline $\begin{array}{l}\text { International Journal of } \\
\text { Hospitality Management }\end{array}$ & Sox et al. (2014) \\
\hline $\begin{array}{l}\text { Journal of Management } \\
\text { Information Systems }\end{array}$ & Suh et al. (2017) \\
\hline $\begin{array}{l}\text { International Journal of } \\
\text { Human Computer Studies }\end{array}$ & Xi et al. (2019) \\
\hline
\end{tabular}




\subsection{Number of studies by industry}

Table 3 demonstrates the range of industries that have taken interest in the gamification phenomena. Most articles, 5 out of 41 , were written for the banking sector. However, these 5 studies came from just two teams of scholars. It would seem that when researchers examine a special tool or system of gamification, more variables are needed to judge whether the system has had a positive impact on the business. Sport, marketing, IT/software and tourism are the four industries where three empirical papers were

Table 3. The industries examined by the final selection of business-related gamification articles

\begin{tabular}{|c|c|}
\hline Industry & Articles \\
\hline Bank & $\begin{array}{l}\text { Baxter et al. (2017) } \\
\text { Baxter et al. (2016) } \\
\text { Rodrigues et al. (2016a) } \\
\text { Rodrigues et al. (2016b) } \\
\text { Rodrigues et al. (2016c) }\end{array}$ \\
\hline Sport & $\begin{array}{l}\text { Högberg et al. (2019a) } \\
\text { Huang et al. (2019) } \\
\text { Jang et al. (2018) }\end{array}$ \\
\hline Marketing & $\begin{array}{l}\text { Conaway and Garay (2014) } \\
\text { Lucassen and Jansen (2014) } \\
\text { Xi et al. (2019) }\end{array}$ \\
\hline IT/Software & $\begin{array}{l}\text { Eisingerich et al. (2019) } \\
\text { García et al. (2017) } \\
\text { Park et al. (2019) }\end{array}$ \\
\hline Tourism & $\begin{array}{l}\text { Liang et al. (2017) } \\
\text { Moro et al. (2019) } \\
\text { Sigala (2015) }\end{array}$ \\
\hline Trading services & $\begin{array}{l}\text { Hamari (2013) } \\
\text { Hamari (2017) }\end{array}$ \\
\hline Coffee & $\begin{array}{l}\text { Kim and Ahn (Grace) (2017) } \\
\text { Li (2017) }\end{array}$ \\
\hline Environmental & $\begin{array}{l}\text { Hsu et al. (2017) } \\
\text { Hsu and Chen (2018a) }\end{array}$ \\
\hline Car manufacturing & $\begin{array}{l}\text { Kampker et al. (2014) } \\
\text { Köse et al. (2019) }\end{array}$ \\
\hline FMCG & $\begin{array}{l}\text { Högberg et al. (2019b) } \\
\text { Lounis et al. (2013) }\end{array}$ \\
\hline Retail & $\begin{array}{l}\text { Poncin et al. (2017) } \\
\text { Hsu and Chen (2018b) }\end{array}$ \\
\hline Research & Bailey et al. (2015) \\
\hline Childcare & Fernandes et al. (2012) \\
\hline $\begin{array}{l}\text { Meeting, expositions, events, } \\
\text { and conventions }\end{array}$ & Sox et al. (2014) \\
\hline Consulting & Suh et al. (2017) \\
\hline Food processing & Yang et al. (2017) \\
\hline Consumer electronics & $\mathrm{Xi}$ and Hamari (2019) \\
\hline Not specified & $\begin{array}{l}\text { Alcivar and Abad (2016) } \\
\text { Dissanayake et al. (2019) } \\
\text { Feng et al. (2018) } \\
\text { Landers et al. (2017) } \\
\text { Leclercq et al. (2018) } \\
\text { Leszczyński and Zakrzewicz } \\
\text { (2019) }\end{array}$ \\
\hline
\end{tabular}

examined in this study. We have also a high variety of industries to which gamification was applied, from trading services, through car manufacturing to consulting. There were 6 studies (e.g., Alcivar \& Abad, 2016; Landers et al., 2017) which were not allocated to specific industry because they examined issues that run across a number of industries, such as employee performance and employee learning. Other studies (Dissanayake et al., 2019; Feng et al., 2018; Leclercq et al., 2018) analysed the effects of gamification in a crowdsourcing platform environment affecting multiple industries. The remaining 18 articles were dispersed over 12 different industries, indicating a wide-spread and broad interest in the gaming phenomena.

\subsection{Number of studies by orientation}

One of the purposes of this study was to show whether organisations apply gamification to enhance the performance of their employees or motivate and engage their customers. We may consider increasing the performance of the employees as a human resource management issue and enhancing brand loyalty and motivations of customers to buy a product or choose services provided by the company as a marketing issue. Figure 4 shows that of the 41 articles, 32 focused on the customers and 9 on the employees. In other words, gamification placed more than three times more emphasis on marketing than on HRM. One explanation for this imbalance may be that gamifying a customer environment can reach more people, possibly with a larger impact on achieving business goals than gamifying a work environment.

\subsection{Studies by type of implementation}

There are wide possibilities for business professionals to implement a gamification process to help achieve their businesses goals. The review of the selected articles reveals that organisations have adopted gamification mostly through the design of their webpage, especially when interacting with their customers. For instance, in the Banking industry, a gamified webpage environment can prove

Number of articles by orientation

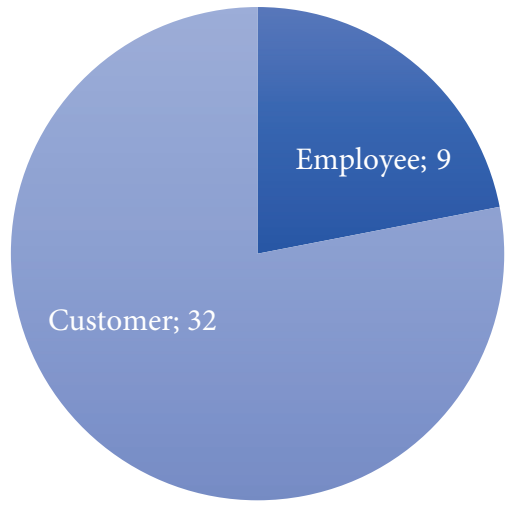

Figure 4. The comparison of the final selection of gamification articles regarding their employee and customer orientation 
much more engaging for the customers through creative web designs. Several companies have developed mobile applications to better communicate their brands. We note that of the 41 selected articles, nine articles were related to this type of implementations. Articles that examined gamification through a mobile application were mainly written in the recent years. Gamifying through mobile applications is a recent phenomenon. It is expected that the implementation of gamification would not compromise the hedonic and utilitarian requirement of the customers. Gamifying a consumer environment is focused on the shopping or service processes. The webpage is only a part of the gamification process. Another large cohort of articles was related to implementation of gamified trainings of the employees. Gamification can also appear in ERP systems, crowdsourcing platforms, loyalty programs or even in brainstorming tasks among employees. Our results are presented in Table 4.

\subsection{Gamification elements used in the studies}

An investigation of gamification elements used in the studies yielded no unexpected results. Rewards was the most used motivating element, appearing in 15 articles. Badges was the second most used element, appearing in 14 cases. Points were the third most used gamification technique among researchers, while Leaderboards, Levels, Social interactions, Challenges, Feedback, Competitions and Progress followed, in that order. The results are in line with the findings of Hamari et al. (2014), Dicheva et al. (2015) and Bharathi et al. (2016). These elements often overlap, as seen between Rewards and Badges. Categorization of elements in terms of dynamics, mechanics, and components described by Werbach and Hunter (2012, p. 82) offers another way of understanding the impact of gamification. However, it is important to recognize that at times the categories may be confounded; for instance, in some situations differentiation may be a challenge; gamification dynamics may at times also be considered a component. Social interaction may contain other components such as
Table 4. Implementation type of gamification in the final selection of articles

\begin{tabular}{|c|c|}
\hline Types of implementation & Articles \\
\hline Web page design & $\begin{array}{l}\text { Hsu et al. (2017) } \\
\text { Hsu and Chen (2018a) } \\
\text { Hsu and Chen (2018b) } \\
\text { Leszczyński and Zakrzewicz (2019) } \\
\text { Liang et al. (2017) } \\
\text { Moro et al. (2019) } \\
\text { Rodrigues et al. (2016a) } \\
\text { Rodrigues et al. (2016b) } \\
\text { Rodrigues et al. (2016c) } \\
\text { Sigala (2015) } \\
\text { Xi and Hamari (2019) }\end{array}$ \\
\hline Mobile applications & $\begin{array}{l}\text { Eisingerich et al. (2019) } \\
\text { Högberg et al. (2019a) } \\
\text { Högberg et al. (2019b) } \\
\text { Huang et al. (2019) } \\
\text { Jang et al. (2018) } \\
\text { Köse et al. (2019) } \\
\text { Li (2017) } \\
\text { Xi et al. (2019) } \\
\text { Yang et al. (2017) }\end{array}$ \\
\hline Consumer environment & $\begin{array}{l}\text { Conaway and Garay (2014) } \\
\text { Hamari (2013) } \\
\text { Hamari (2017) } \\
\text { Lounis et al. (2013) } \\
\text { Lucassen and Jansen (2014) }\end{array}$ \\
\hline Training & $\begin{array}{l}\text { Alcivar and Abad (2016) } \\
\text { Baxter et al. (2017) } \\
\text { Baxter et al. (2016) } \\
\text { Kampker et al. (2014) } \\
\text { Park et al. (2019) } \\
\end{array}$ \\
\hline Crowdsourcing platform & $\begin{array}{l}\text { Dissanayake et al. (2019) } \\
\text { Feng et al. (2018) } \\
\text { Leclercq et al. (2018) }\end{array}$ \\
\hline Online survey & Bailey et al. (2015) \\
\hline Requirement elicitation & Fernandes et al. (2012) \\
\hline Work environment & García et al. (2017) \\
\hline Loyalty program & Kim and Ahn (Grace) (2017) \\
\hline Brainstorming task & Landers et al. (2017) \\
\hline $\begin{array}{l}\text { Smart technology } \\
\text { interface }\end{array}$ & Poncin et al. (2017) \\
\hline Meeting environment & Sox et al. (2014) \\
\hline Information System & Suh et al. (2017) \\
\hline
\end{tabular}

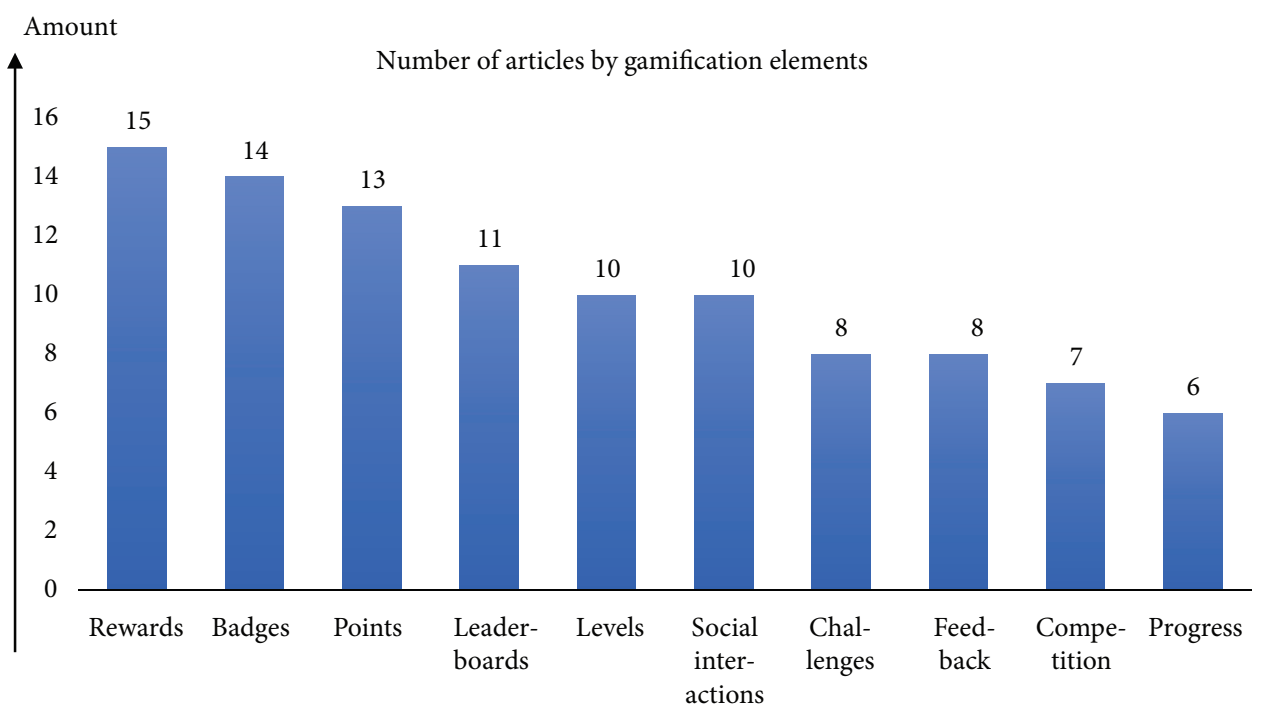

Figure 5. Gamification elements that are analysed in 6 or more studies from the final selection of articles 
Sharing, Feedback and Messaging that can be identified in the analysed articles as well. The gamification elements used in at least 6 studies can be seen in Figure 5. Our findings are consistent with those of Dicheva et al. (2015).

\subsection{Differing effects on companies}

It was also a goal of this study to examine whether gamifying processes applied to businesses have positive, negative, or neutral effects. As shown in Figure 6, it can be stated that generally gamification had a positive effect on the measured variables in most of the studies. Neutral results were seen in four cases, suggesting that gamification did not have a significant effect on the variables examined. Mixed results category contains those articles where gamification had a significant positive impact on the examined variables but resulted negative effects on others at the same time. Only six study reached such a result. One of the articles from the final selection did not provide an indication of the effects of gamification. It tested a design system to introduce gamification and the conclusions from the empirical data were related to the efforts required for the gamification project. It included the support architecture and tool required for adopting an integral gamification solution. The authors mentioned as well that analysing the benefits of gamification was out of their scope. However, as the exclusion criteria did not include a requirement that could have resulted in the exclusion of this article, it was retained in the analysis. Overall, the results show that gamification should be considered for business purposes too, because it can enhance the engagement and loyalty of the customers, and also the motivation and performance of the employees. Earlier review articles too have reported similar results: Gamification yields 888 positive impacts on variables such as engagement, attendance and participant contribution. Gamification provided mixed or negative outcomes in only a few cases (Dicheva et al. (2015).

\subsection{Examined variables in gamification}

In the selected articles, the scholars examined a variety of variables. These are described in Table 5. Engagement was the most cited variable. Engagement can be related either to customers or employees. Enjoyment and usefulness were analysed in nine and seven studies respectively, which is in line with the assumptions that the main purpose of gamification is to provide hedonic and utilitarian values. Knowledge is relevant to the training phase of gamification. Brand Loyalty and Ease of Use are additional topics that appear in five studies each. Besides Business Impact, Satisfaction and User/Customer Experience are topics which were analysed in more than four different articles. It is important to note that gamification can impact a diverse range of variables that corresponds to a range of perspectives of the environment in which gamification is applied. Therefore, one might see different gamification designs in different cases. Dicheva et al. (2015), in the Education sector, had indicated that the most used variables were engagement, attendance, the quantity of student contributions, increased percentage of pass marks in students, motivation and interest. In Business applications, too, engagement, knowledge, and motivation were important.

Table 5. Variables examined in the final selection of gamification articles

\begin{tabular}{|c|c|}
\hline Examined variables & Articles \\
\hline Engagement & $\begin{array}{l}\text { Bailey et al. (2015) } \\
\text { Eisingerich et al. (2019) } \\
\text { Högberg et al. (2019a) } \\
\text { Högberg et al. (2019b) } \\
\text { Jang et al. (2018) } \\
\text { Lucassen and Jansen (2014) } \\
\text { Leclercq et al. (2018) } \\
\text { Park et al. (2019) } \\
\text { Sigala (2015) } \\
\text { Sox et al. (2014) } \\
\text { Yang et al. (2017) }\end{array}$ \\
\hline
\end{tabular}

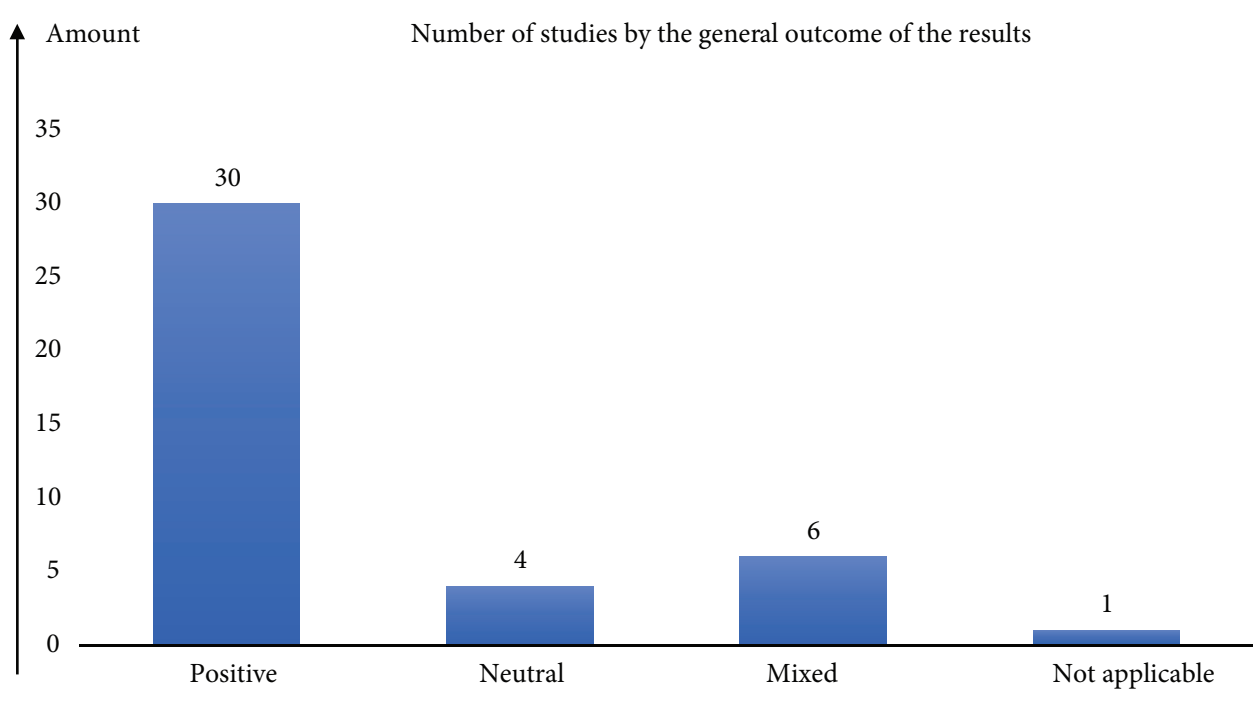

Figure 6. The distribution of the final selection of articles regarding the general impact of gamification and whether it was positive, neutral, mixed or not applicable 


\begin{tabular}{|c|c|c|c|}
\hline Examined variables & Articles & Examined variables & Articles \\
\hline \multirow[t]{4}{*}{ Enjoyment } & \multirow{4}{*}{$\begin{array}{l}\text { Baxter et al. (2017) } \\
\text { Baxter et al. (2016) } \\
\text { Dissanayake et al. (2019) } \\
\text { Hsu and Chen (2018b) } \\
\text { Huang et al. (2019) } \\
\text { Köse et al. (2019) } \\
\text { Rodrigues et al. (2016b) } \\
\text { Rodrigues et al. (2016c) } \\
\text { Xi et al. (2019) }\end{array}$} & Task performance & $\begin{array}{l}\text { Dissanayake et al. (2019) } \\
\text { Landers et al. (2017) }\end{array}$ \\
\hline & & Perceived value & $\begin{array}{l}\text { Hsu et al. (2017) } \\
\text { Hsu and Chen (2018a) }\end{array}$ \\
\hline & & Receive Reviews & $\begin{array}{l}\text { Leszczyński and Zakrzewicz (2019) } \\
\text { Liang et al. (2017) }\end{array}$ \\
\hline & & Social bonds / value & $\begin{array}{l}\text { Feng et al. (2018) } \\
\text { Huang et al. (2019) }\end{array}$ \\
\hline \multirow[t]{4}{*}{ Usefulness } & \multirow{4}{*}{$\begin{array}{l}\text { Fernandes et al. (2012) } \\
\text { Hsu and Chen (2018a) } \\
\text { Hsu and Chen (2018b) } \\
\text { Huang et al. (2019) } \\
\text { Köse et al. (2019) } \\
\text { Rodrigues et al. (2016b) } \\
\text { Rodrigues et al. (2016c) }\end{array}$} & Playfulness & $\begin{array}{l}\text { Feng et al. (2018) } \\
\text { Park et al. (2019) }\end{array}$ \\
\hline & & $\begin{array}{l}\text { Discontinuance } \\
\text { intention }\end{array}$ & $\begin{array}{l}\text { Huang et al. (2019) } \\
\text { Köse et al. (2019) }\end{array}$ \\
\hline & & Data validity & Bailey et al. (2015) \\
\hline & & Implementation & García et al. (2017) \\
\hline \multirow[t]{3}{*}{ Brand loyalty } & \multirow{3}{*}{$\begin{array}{l}\text { Högberg et al. (2019a) } \\
\text { Hsu and Chen (2018a) } \\
\text { Hsu and Chen (2018b) } \\
\text { Kim and Ahn (Grace) (2017) } \\
\text { Lucassen and Jansen (2014) } \\
\end{array}$} & suitability & \\
\hline & & $\begin{array}{l}\text { Implementation } \\
\text { efficiency }\end{array}$ & García et al. (2017) \\
\hline & & Characteristics of & Conaway and Garay (2014) \\
\hline \multirow[t]{3}{*}{ Knowledge } & \multirow{3}{*}{$\begin{array}{l}\text { Alcivar and Abad (2016) } \\
\text { Baxter et al. (2017) } \\
\text { Baxter et al. (2016) } \\
\text { Kim and Ahn (Grace) (2017) } \\
\text { Park et al. (2019) }\end{array}$} & $\begin{array}{l}\text { incorporate } \\
\text { gamification }\end{array}$ & \\
\hline & & Attitude & Hsu et al. (2017) \\
\hline & & Switching between & Li (2017) \\
\hline \multirow[t]{3}{*}{ Ease of use } & \multirow{3}{*}{$\begin{array}{l}\text { Huang et al. (2019) } \\
\text { Köse et al. (2019) } \\
\text { Rodrigues et al. (2016a) } \\
\text { Rodrigues et al. (2016b) } \\
\text { Rodrigues et al. (2016c) }\end{array}$} & $\begin{array}{l}\text { membership } \\
\text { cards and mobile } \\
\text { applications }\end{array}$ & \\
\hline & & Ratings & Liang et al. (2017) \\
\hline & & Sustainable & Lounis et al. (2013) \\
\hline \multirow{3}{*}{$\begin{array}{l}\text { Business impact / } \\
\text { Purchases }\end{array}$} & \multirow{3}{*}{$\begin{array}{l}\text { Eisingerich et al. (2019) } \\
\text { Högberg et al. (2019b) } \\
\text { Jang et al. (2018) } \\
\text { Rodrigues et al. (2016b) }\end{array}$} & consumption & \\
\hline & & Awareness & Lucassen and Jansen (2014) \\
\hline & & Patronage intentions & Poncin et al. (2017) \\
\hline \multirow[t]{3}{*}{ Intention to use } & \multirow{3}{*}{$\begin{array}{l}\text { Köse et al. (2019) } \\
\text { Rodrigues et al. (2016a) } \\
\text { Rodrigues et al. (2016b) } \\
\text { Rodrigues et al. (2016c) }\end{array}$} & Impact of use & Sigala (2015) \\
\hline & & Flow experience & Suh et al. (2017) \\
\hline & & Aesthetic experience & Suh et al. (2017) \\
\hline \multirow{4}{*}{ Satisfaction } & \multirow{4}{*}{$\begin{array}{l}\text { Högberg et al. (2019a) } \\
\text { Hsu and Chen (2018b) } \\
\text { Huang et al. (2019) } \\
\text { Xi and Hamari (2019) }\end{array}$} & Brand attitude & Yang et al. (2017) \\
\hline & & Effort & Dissanayake et al. (2019) \\
\hline & & Hope & Eisingerich et al. (2019) \\
\hline & & Compulsion & Eisingerich et al. (2019) \\
\hline \multirow{3}{*}{$\begin{array}{l}\text { User/customer } \\
\text { experience }\end{array}$} & \multirow{3}{*}{$\begin{array}{l}\text { Hsu et al. (2017) } \\
\text { Hsu and Chen (2018a) } \\
\text { Leclercq et al. (2018) } \\
\text { Poncin et al. (2017) }\end{array}$} & Self-presentation & Feng et al. (2018) \\
\hline & & Positive affect & Högberg et al. (2019a) \\
\hline & & Perceived mobility & Hsu and Chen (2018a) \\
\hline \multirow[t]{2}{*}{ Self-efficacy } & \multirow{2}{*}{$\begin{array}{l}\text { Dissanayake et al. (2019) } \\
\text { Feng et al. (2018) } \\
\text { Park et al. (2019) }\end{array}$} & Perceived benefits & Hsu and Chen (2018a) \\
\hline & & Brand equity & Hsu and Chen (2018a) \\
\hline \multirow[t]{2}{*}{ Usage activity } & \multirow{2}{*}{$\begin{array}{l}\text { Hamari (2013) } \\
\text { Hamari (2017) } \\
\text { Xi and Hamari (2019) }\end{array}$} & Brand love & Hsu and Chen (2018b) \\
\hline & & $\begin{array}{l}\text { Positive word of } \\
\text { mouth }\end{array}$ & Hsu and Chen (2018b) \\
\hline \multirow[t]{2}{*}{ Intrinsic motivation } & \multirow{2}{*}{$\begin{array}{l}\text { Dissanayake et al. (2019) } \\
\text { Kim and Ahn (Grace) (2017) } \\
\text { Sigala (2015) }\end{array}$} & $\begin{array}{l}\text { Resistance to negative } \\
\text { information }\end{array}$ & Hsu and Chen (2018b) \\
\hline & & Confirmation & Huang et al. (2019) \\
\hline \multirow[t]{2}{*}{ Hedonic value } & $\begin{array}{l}\text { Högberg et al. (2019a) } \\
\text { Hsu and Chen (2018a) }\end{array}$ & Habit & Huang et al. (2019) \\
\hline & Hsuret al (2017) & Regret & Huang et al. (2019) \\
\hline Behavioural intention & Sigala (2015) & Contribution & Köse et al. (2019) \\
\hline
\end{tabular}


End of Table 5

\begin{tabular}{|l|l|}
\hline \multicolumn{1}{|c|}{ Examined variables } & \multicolumn{1}{c|}{ Articles } \\
\hline User conception & Köse et al. (2019) \\
\hline Review length & Moro et al. (2019) \\
\hline $\begin{array}{l}\text { Sentiment charge of } \\
\text { a review }\end{array}$ & Moro et al. (2019) \\
\hline Perceived control & Xi et al. (2019) \\
\hline Interaction time & Xi et al. (2019) \\
\hline Mental simulation & Xi et al. (2019) \\
\hline
\end{tabular}

It is evident that gamifying a webpage or customer environment and training were popular among the researchers especially in the Banking, Trading service and Marketing industry. However, these kinds of implementations can also be investigated in other industries. Figure 7 highlights the types of gamification environment that have not yet been studied through empirical research.

Gamification features have been well-examined in the consumer environment and in webpages. However, there are elements that have not yet been investigated. Figure 7 and Figure 8 reveal the gaps in the literature. In the work

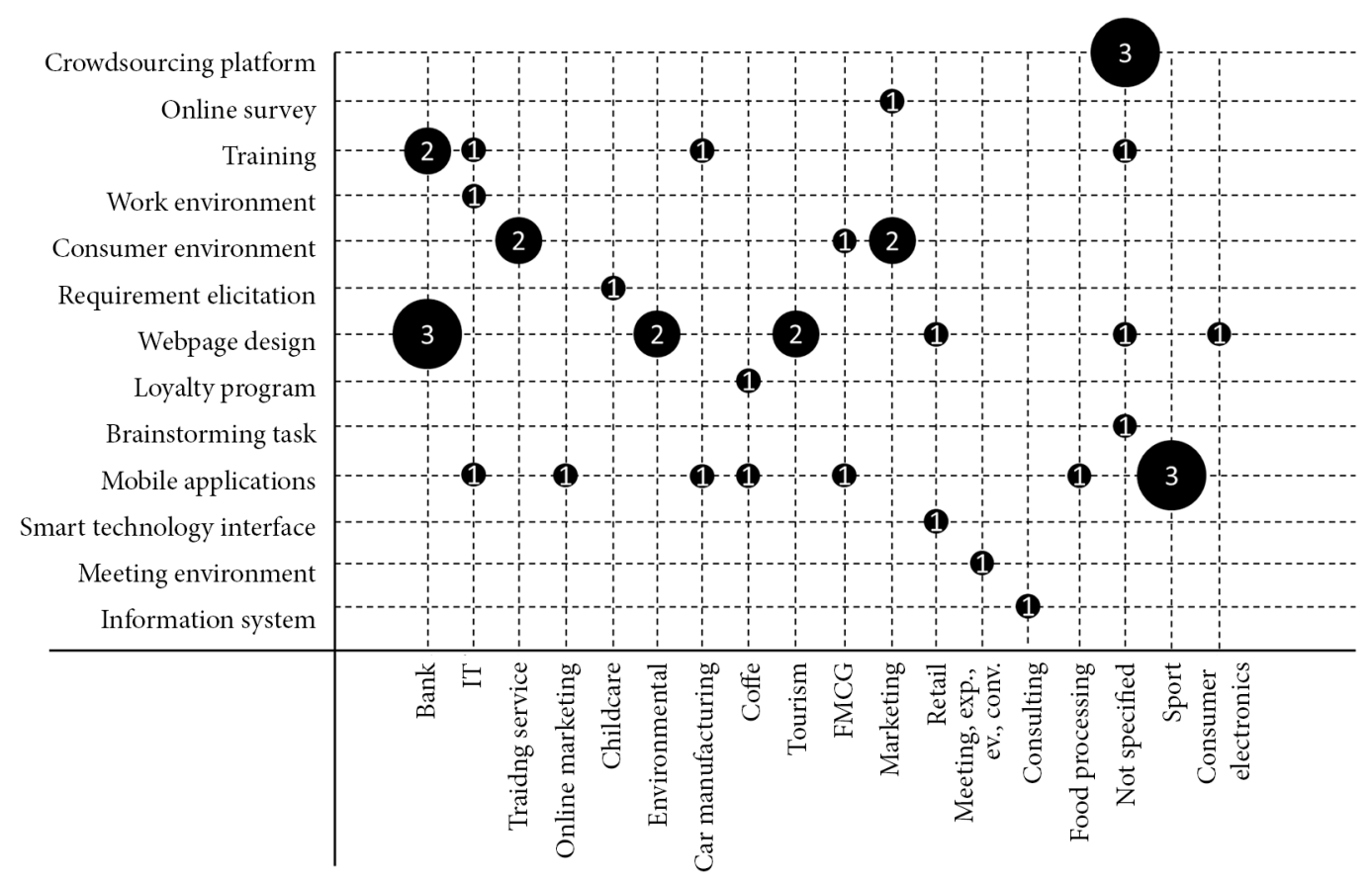

Figure 7. Map of the number of articles by the type of implementation and industry

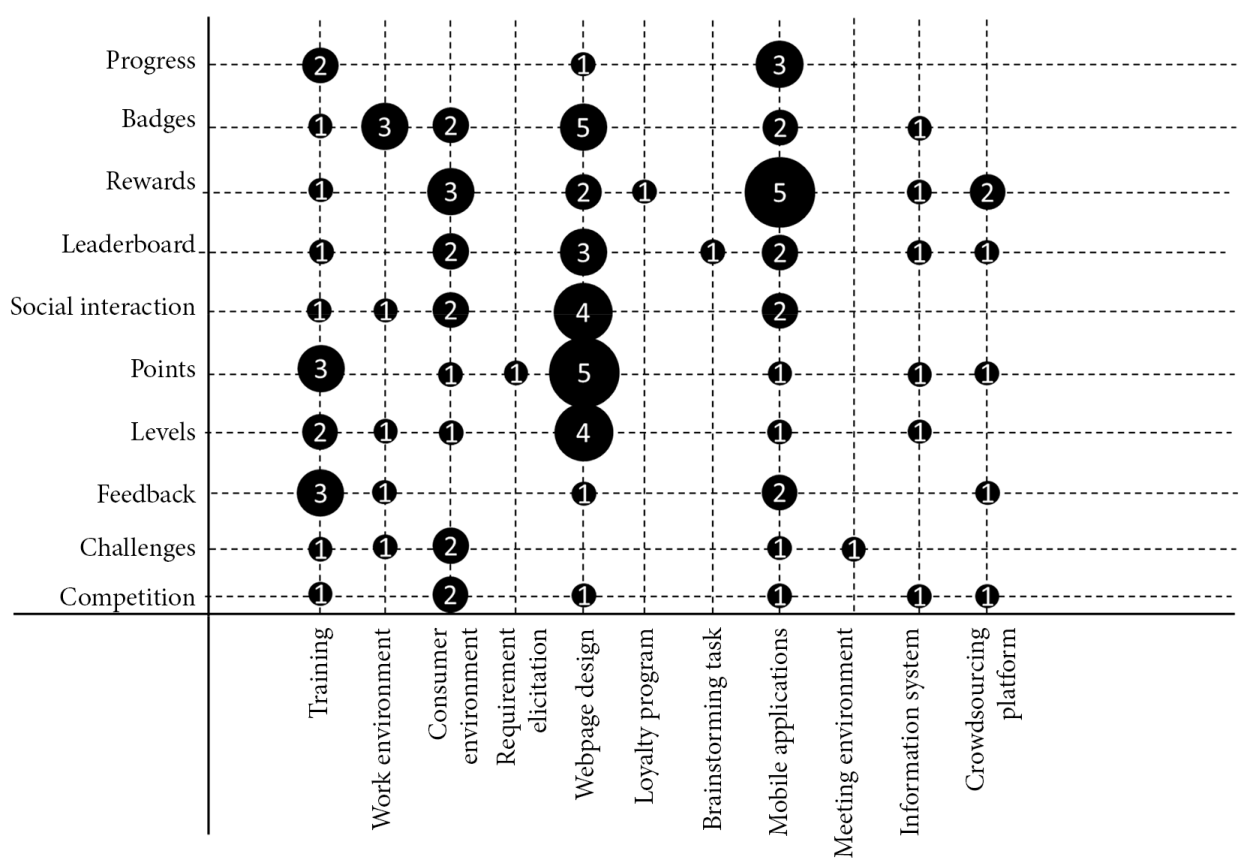

Figure 8. Map of the number of articles by the 10 most used gamification elements and the type of implementation 
environment, some common elements (e.g. rewards, leader boards, points) have not yet been examined. In webpage design, the effects of challenges, which is one of the most popular gamification features, also has not yet been studied. There are other types of implementation environments as well with none or merely one gamification elements investigated. One may conclude that the most investigated implementation areas have provided the most of the popular gamification elements among the researchers.

\section{Discussion}

The purpose of this study was to examine recent trends in gamification research and applications in 'for-profit business organisations. To execute such an investigation, we proceeded with a mapping study. From 639 articles collected from different search databases, we chose a final pool of 41 empirical studies for further review. These papers were then divided into subtopics that were identified as characteristic of the gamification process. We found that in the recent years the number of empirical studies related to gamification in businesses has grown faster than the overall number of papers on the general topic of gamification. The earlier articles focused on setting a framework, elaborating a theory, and in subsequent years these theories led to empirical assessment.

If we view the range of companies and industries where gamification was applied, we can conclude that the application of gamification is not restricted to only specific businesses. In fact, it is indicated that with a careful planning and smart design it can be implemented in every area of businesses. We see that individual sets of researchers who reported on more than one empirical study, focused on one specific industry. Also, they analysed similar variables in those studies. We suspect that it is not possible to provide a unified gamification process for different type of companies. The process needs to be well-elaborated and tailored for specific environments and designed for specific purposes to achieve the best possible outcomes.

Gamification being applied with greater frequency to customer related issues suggests that customers are held at higher priority by the practitioners than the employees. In the short term, a company can benefit more from focusing on customer-related gamification by reaching more people affecting the revenues or returns than through gamification of employee-related issues

The area to which gamification was applied the most was the webpage design. Customer environment was the third most addressed area. However, the two could well be related. A well-designed company web-page could target many customers. For instance, a gamification process applied to the web-page design might ease the shopping experience of the customer. Another emerging trend is the use of gamified mobile applications facilitates remote interaction with customers. Training of employees, too, was an area where gamification was implemented in several studies. It seems that gamification in human resource management is used mainly in employee training to increase motivation and learning outcome. Badges, rewards, and leader boards were the primary game elements deployed. This finding is consistent with the findings of previously reported studies. There are a number of possible elements and components of gamification. It is a challenge for the designers to select an optimal set for maximum benefit. For this reason, a well-elaborated hierarchy is needed regarding the gamification dynamics, mechanics, and components, excluding the possible overlaps that can exist between gamification elements.

Another purpose of this study was to examine whether gamification had an overall positive influence on the analysed variables in the selected business-related gamification articles. Indeed, in most cases gamification resulted in higher customer or employee engagement. These were the most examined areas among the studies. Knowledge, brand loyalty, user experience, and usefulness were also analysed in more than one article.

While the existing literature already reports gamification applied to the banking and marketing, such applications yet need to be investigated in other fields to prove the effects of gamification. Further, research is also needed on measuring more gamification elements in work environments. For instance, gamification features can also be applied to loyalty programs and mobile applications. In web-page design, too, there are popular gamification elements that have not yet been examined. The studies also need to focus on a concise hierarchy to exclude the overlaps among gamification elements. This requires that gamification dynamics, mechanics, and components should be well divided, providing a clear understanding of components that have a positive effect on the analysed variables. Studies are also needed to identify the elements that are most suitable in different industries and business environments. Another research direction would be to analyse the type of users and categorize them to determine which gamification elements are the most appropriate for different user-type. It would be helpful to design the most appropriate gamification system for the specific users to achieve greater benefits.

Although this study contributes to the existing literature related to gamification in "for-profit" business organisations, it has also some limitations. First, the relevant articles could have been collected from more databases. Secondly, this analysis was limited to gamification only in a business-related context. It excluded studies available in other fields, such as education. Another limitation is that all the data were gathered from prior studies and it only contained analysis to determine the main trends, the most used gamification elements and the most analysed variables through gamification. Reflecting reliability and validity of research in this article, they can be increased by widening the topic of gamification in education, or the inclusion criteria to qualitative studies. 


\section{Conclusions}

The purpose of this study was to provide an overview of the existing literature on business-related gamification. The studies analysed contains empirical research which provides a good basis for the understanding of areas of gamification in for-profit organisations. We have identified areas that have already been examined and also areas that can be analysed further. This study also provides a collection of empirical articles about business-related gamification that can serve as an overview of the literature. These articles were examined for numbers and proportions of specific aspects of for-profit organisations: (i) industry, (ii) companies' orientation, (iii) implementation, (iv) elements, (v) effects on operation, and (vi) gamification variables. The six fields of research were based on the existing literature and were identified prior to the analysis; however, the details for each were added during the overview and examination of the articles. With this, researchers may use our article as a map of the dominating industries, companies' orientation, ways of implementation, gamification elements, effects on companies and variables in the academic papers of the selected databases.

The basic assumption of this paper is that the current gamification literature base reflects trends in practice. The managerial implications suggest hypotheses for further empirical research. Our findings suggest that overall, gamification offers positive impact on various factors such as motivation, knowledge, and enjoyment. Most of the collected studies claimed that gamification positively influenced the employees or customers in terms of their knowledge, attitude or brand loyalty. This means that gamification is a proven tool that can improve the operations of business organisations. Gamification can have a positive impact on business processes in different ways. Managers may consider applying gamification either to increase employee performance or motivation or they can use gamification to attract more engaged customers and increase their brand loyalty. It is important for practitioners to know that gamification is not a magic formula and will not automatically result in the expected outcomes unless it is planned and designed carefully. This means that first, managers need to define the purpose of applying gamification to their processes and what they would like to achieve with it. Next, they need to define the characteristics of their employees or customers. Through this paper, a practitioner who seeks a tool to positively influence their employees or customers, can receive a clearer picture of what gamification is, what elements may be targeted, and which variables can be positively influenced by gamification. The study also provides insight into the types of implementation in different industries, and whether gamification can be applied in their business context.

\section{Acknowledgements}

We are thankful to several participants for their comments on the presentation of previous versions of the paper and reviewers, who contributed to the final version of the paper. We are also grateful to the Hungarian Central Bank, which support the studies of the first author.

\section{Funding}

This work was supported by the Centre for Higher Education and Industrial Cooperation under Grant [GINOP-2.3.4-15-2016-00003]

\section{References}

Adukaite, A., van Zyl, I., Er, Ş., \& Cantoni, L. (2017). Teacher perceptions on the use of digital gamified learning in tourism education: The case of South African secondary schools. Computers \& Education, 111, 172-190.

https://doi.org/10.1016/j.compedu.2017.04.008

Alcivar, I., \& Abad, A. G. (2016). Design and evaluation of a gamified system for ERP training. Computers in Human Behavior, 58, 109-118. https://doi.org/10.1016/j.chb.2015.12.018

Bailey, P., Pritchard, G., \& Kernohan, H. (2015). Gamification in market research: Increasing enjoyment, participant engagement and richness of data, but what of data validity? International Journal of Market Research, 57(1), 17. https://doi.org/10.2501/IJMR-2015-003

Barata, G., Gama, S., Jorge, J., \& Gonçalves, D. (2015). Gamification for smarter learning: tales from the trenches. Smart Learning Environments, 2(1), 10.

https://doi.org/10.1186/s40561-015-0017-8

Baxter, R. J., Holderness Jr., D. K., \& Wood, D. A. (2016). Applying basic gamification techniques to IT compliance training: evidence from the lab and field. Journal of Information Systems, 30(3), 119-133.

https://doi.org/10.1017/CBO9781107415324.004

Baxter, R. J., Holderness, D. K., \& Wood, D. A. (2017). The effects of gamification on corporate compliance training: a partial replication and field study of true office anti-corruption training programs. Journal of Forensic Accounting Research, 2(1), A20-A30. https://doi.org/10.2308/jfar-51725

Bharathi, A. K. B. G., Singh, A., Tucker, C. S., \& Nembhard, H. B. (2016). Knowledge discovery of game design features by mining user-generated feedback. Computers in Human Behavior, 60, 361-371. https://doi.org/10.1016/j.chb.2016.02.076

Boyle, S. C., Earle, A. M., LaBrie, J. W., \& Smith, D. J. (2017). PNF 2.0? Initial evidence that gamification can increase the efficacy of brief, web-based personalized normative feedback alcohol interventions. Addictive Behaviors, 67, 8-17. https://doi.org/10.1016/j.addbeh.2016.11.024

Buckley, P., \& Doyle, E. (2017). Individualising gamification: An investigation of the impact of learning styles and personality traits on the efficacy of gamification using a prediction market. Computers and Education, 106, 43-55. https://doi.org/10.1016/j.compedu.2016.11.009

Bunchball, I. (2010). Gamification 101: An introduction to the use of game dynamics to influence behavior. White Paper, 9.

Businesswire. (n.d.). Global Gamification Market to Exceed USD 6 Billion by 2019, According to Technavio. Business Wire. http://www.businesswire.com/news/home/20160308005109/ en/Global-Gamification-Market-Exceed-USD-6-BillionFirefoxHTML/Shell/Open/Command

Chou, Y. K. (2015). Actionable gamification: Beyond points, badges, and leaderboards. Octalysis Group. 
Conaway, R., \& Garay, M. C. (2014). Gamification and service marketing. SpringerPlus, 3(1), 653. https://doi.org/10.1186/2193-1801-3-653

Costa, C. J., Aparicio, M., Aparicio, S., \& Aparicio, J. T. (2017, August). Gamification usage ecology. In Proceedings of the 35th ACM International Conference on the Design of Communication (p. 2). ACM. https://doi.org/10.1145/3121113.3121205

Dale, S. (2014). Gamification: Making work fun, or making fun of work? Business Information Review, 31(2), 82-90.

https://doi.org/10.1177/0266382114538350

de Sousa Borges, S., Durelli, V. H., Reis, H. M., \& Isotani, S. (2014, March). A systematic mapping on gamification applied to education. In Proceedings of the 29th Annual ACM Symposium on Applied Computing (pp. 216-222). ACM. https://doi.org/10.1145/2554850.2554956

Deterding, S., Dixon, D., Khaled, R., \& Nacke, L. (2011, September). From game design elements to gamefulness: defining "gamification". In Proceedings of the 15th international academic MindTrek conference: Envisioning future media environments (pp. 9-15). New York, United States. https://doi.org/10.1145/2181037.2181040

Dicheva, D., Dichev, C., Agre, G., \& Angelova, G. (2015). Gamification in education: A systematic mapping study. Journal of Educational Technology \& Society, 18(3).

Dissanayake, I., Mehta, N., Palvia, P., Taras, V., \& AmoakoGyampah, K. (2019). Competition matters! Self-efficacy, effort, and performance in crowdsourcing teams. Information \& Management, 56(8), 103158.

https://doi.org/10.1016/j.im.2019.04.001

Eisingerich, A. B., Marchand, A., Fritze, M. P., \& Dong, L. (2019). Hook vs. hope: How to enhance customer engagement through gamification. International Journal of Research in Marketing, 36(2), 200-215. https://doi.org/10.1016/j.ijresmar.2019.02.003

Ėrgle, D. (2016). AirBaltic case based analysis of potential for improving employee engagement levels in Latvia through Gamification. Economics and Business, 28(1), 45-52. https://doi.org/10.1515/eb-2016-0007

Eynard, B., Oliveri, S. M., \& Peris-Fajarnes, G. (2017, September). Advances on mechanics, design engineering and manufacturing. Procedings of the International Joint Conference on Mechanics, Design Engineering \& Advanced Manufacturing (JCM) (pp. 14-16). Catania, Italy. https://doi.org/10.1007/978-3-319-45781-9

Fekete, D. (2018). Development and economic governance through the example of the city of Györ. DETUROPE: Central European Journal of Tourism and Regional Development, 10(1), 97-115.

Feng, Y., et al. (2018). Gamification artifacts and crowdsourcing participation: Examining the mediating role of intrinsic motivations. Computers in Human Behavior, 81, 124-136. https://doi.org/10.1016/j.chb.2017.12.018

Fernandes, J., Duarte, D., Ribeiro, C., Farinha, C., Pereira, J. M., \& da Silva, M. M. (2012). iThink: A game-based approach towards improving collaboration and participation in requirement elicitation. Procedia Computer Science, 15, 66-77. https://doi.org/10.1016/j.procs.2012.10.059

Fisher, D. J., Beedle, J., \& Rouse, S. E. (2014). Gamification: a study of business teacher educators' knowledge of, attitudes toward, and experiences with the gamification of activities in the classroom. Journal for Research in Business Education, 56(1), 1-16. https://reddog.rmu.edu/login?url=http://search. ebscohost.com/login.aspx?direct $=$ true $\& \mathrm{db}=\mathrm{ehh} \& \mathrm{AN}=11509$ $9505 \&$ site $=$ ehost-live \&scope $=$ site
Fitz-Walter, Z., Johnson, D., Wyeth, P., Tjondronegoro, D., \& Scott-Parker, B. (2017). Driven to drive? Investigating the effect of gamification on learner driver behavior, perceived motivation and user experience. Computers in Human Behavior, 71, 586-595. https://doi.org/10.1016/j.chb.2016.08.050

García, F., Pedreira, O., Piattini, M., Cerdeira-Pena, A., \& Penabad, M. (2017). A framework for gamification in software engineering. Journal of Systems and Software, 132, 21-40. https://doi.org/10.1016/j.jss.2017.06.021

Gartner Study. (2012). Gamification 2020: What Is the Future of Gamification? https://www.gartner.com/doc/2226015/gamification--future-gamification

Hamari, J. (2013). Transforming homo economicus into homo ludens: A field experiment on gamification in a utilitarian peer-to-peer trading service. Electronic Commerce Research and Applications, 12(4), 236-245.

https://doi.org/10.1016/j.elerap.2013.01.004

Hamari, J. (2017). Do badges increase user activity? A field experiment on the effects of gamification. Computers in Human Behavior, 71, 469-478.

https://doi.org/10.1016/j.chb.2015.03.036

Hamari, J., Koivisto, J., \& Sarsa, H. (2014). Does gamification work? A literature review of empirical studies on gamification. In 47th Hawaii International Conference on System Sciences (pp. 3025-3034). IEEE.

https://doi.org/10.1109/HICSS.2014.377

Herzig, P., Ameling, M., \& Schill, A. (2012). A generic platform for enterprise gamification. In 2012 Joint Working IEEE/IFIP Conference on Software Architecture and European Conference on Software Architecture (pp. 219-223). IEEE. https://doi.org/10.1109/WICSA-ECSA.212.33

Högberg, J., et al. (2019a). Creating brand engagement through in-store gamified customer experiences. Journal of Retailing and Consumer Services, 50(November 2018), 122-130. https://doi.org/10.1016/j.jretconser.2019.05.006

Högberg, J., Shams, P., \& Wästlund, E. (2019b). Gamified instore mobile marketing: The mixed effect of gamified pointof-purchase advertising. Journal of Retailing and Consumer Services, 50(July 2018), 298-304.

https://doi.org/10.1016/j.jretconser.2018.07.004

Hsu, C. L., Chen, Y. C., Yang, T. N., \& Lin, W. K. (2017). Do website features matter in an online gamification context? Focusing on the mediating roles of user experience and attitude. Telematics and Informatics, 34(4), 196-205. https://doi.org/10.1016/j.tele.2017.01.009

Hsu, C. L., \& Chen, M. C. (2018a). How does gamification improve user experience? An empirical investigation on the antecedences and consequences of user experience and its mediating role. Technological Forecasting and Social Change, 132(November 2017), 118-129.

https://doi.org/10.1016/j.techfore.2018.01.023

Hsu, C. L., \& Chen, M. C. (2018b). How gamification marketing activities motivate desirable consumer behaviors: Focusing on the role of brand love. Computers in Human Behavior, 88(May), 121-133. https://doi.org/10.1016/j.chb.2018.06.037

Huang, C. K., Chen, C. Der, \& Liu, Y. T. (2019). To stay or not to stay? Discontinuance intention of gamification apps. Information Technology and People, 32(6), 1423-1445. https://doi.org/10.1108/ITP-08-2017-0271

Huber, M. Z., \& Hilty, L. M. (2015). ICT innovations for sustainability. Advances in Intelligent Systems and Computing, 310, 367-385. https://doi.org/10.1007/978-3-319-09228-7

Jang, S., Kitchen, P. J., \& Kim, J. (2018). The effects of gamified customer benefits and characteristics on behavioral engage- 
ment and purchase: Evidence from mobile exercise application uses. Journal of Business Research, 92(July), 250-259. https://doi.org/10.1016/j.jbusres.2018.07.056

Jiménez, S., \& Escribano, F. (2015). Gamification model canvas. https://www.gamasutra.com/blogs/SergioJimenez/20131106/204134/Gamification_Model_Canvas.php

Kampker, A., Deutskens, C., Deutschmann, K., Maue, A., \& Haunreiter, A. (2014). Increasing ramp-up performance by implementing the gamification approach. Procedia CIRP, 20, 74-80. https://doi.org/10.1016/j.procir.2014.05.034

Kappen, D. L., \& Nacke, L. E. (2013). The kaleidoscope of effective gamification: deconstructing gamification in business applications In Proceedings of the First International Conference on Gameful Design, Research, and Applications (pp. 119-122). Toronto, Canada. https://doi.org/10.1145/2583008.2583029

Kim, K., \& Ahn, S. J. (Grace). (2017). The role of gamification in enhancing intrinsic motivation to use a loyalty program. Journal of Interactive Marketing, 40, 41-51. https://doi.org/10.1016/j.intmar.2017.07.001

Kim, S. (2015). Interdisciplinary approaches and methods for sustainable transformation and innovation. Sustainability (Switzerland), 7(4), 3977-3983. https://doi.org/10.3390/su7043977

Kitchenham, B. A., Budgen, D., \& Pearl Brereton, O. (2011). Using mapping studies as the basis for further research - A participant-observer case study. Information and Software Technology, 53(6), 638-651.

https://doi.org/10.1016/j.infsof.2010.12.011

Köse, D. B., Morschheuser, B., \& Hamari, J. (2019). Is it a tool or a toy? How user conceptions of a system's purpose affect their experience and use. International Journal of Information Management, 49(July), 461-474.

https://doi.org/10.1016/j.ijinfomgt.2019.07.016

Kuramoto, I., Ishibashi, T., Yamamoto, K., \& Tsujino, Y. (2013). Stand up, heroes!: Gamification for standing people on crowded public transportation. Lecture Notes in Computer Science (Including Subseries Lecture Notes in Artificial Intelligence and Lecture Notes in Bioinformatics), 8013 LNCS(PART 2), 538-547. https://doi.org/10.1007/978-3-642-39241-2_59

Landers, R. N., Bauer, K. N., \& Callan, R. C. (2017). Gamification of task performance with leaderboards: A goal setting experiment. Computers in Human Behavior, 71, 508-515. https://doi.org/10.1016/j.chb.2015.08.008

Leclercq, T., Hammedi, W., \& Poncin, I. (2018). The boundaries of gamification for engaging customers: effects of losing a contest in online co-creation communities. Journal of Interactive Marketing, 44, 82-101.

https://doi.org/10.1016/j.intmar.2018.04.004

Lexico. (n.d.). Gamification - definition of gamification in English. Oxford Dictionaries. https://en.oxforddictionaries.com/ definition/gamification

Leszczyński, K., \& Zakrzewicz, M. (2019). Reviews with revenue in reputation: Credibility management method for consumeropinion platforms. Information Systems, 84, 189-196. https://doi.org/10.1016/j.is.2019.05.005

Li, C.-Y. (2017). Consumer behavior in switching between membership cards and mobile applications: the case of starbucks. Computers in Human Behavior, 84, 171-184. https://doi.org/10.1016/j.chb.2017.12.042

Liang, S., Schuckert, M., Law, R., \& Chen, C. C. (2017). Be a "Superhost": The importance of badge systems for peer-to-peer rental accommodations. Tourism Management, 60, 454-465. https://doi.org/10.1016/j.tourman.2017.01.007

Lopez, C. E., \& Tucker, C. S. (2017). A quantitative method for evaluating the complexity of implementing and performing game features in physically-interactive gamified applications'. Computers in Human Behavior, 71, 42-58.

https://doi.org/10.1016/j.chb.2017.01.036

Lounis, S., Neratzouli, X., \& Pramatari, K. (2013). Can gamification increase consumer engagement? A qualitative approach on a green case. IFIP Advances in Information and Communication Technology, 399, 200-212.

https://doi.org/10.1007/978-3-642-37437-1_17

Lucassen, G., \& Jansen, S. (2014). Gamification in consumer marketing - future or fallacy? Procedia - Social and Behavioral Sciences, 148(2011), 194-202.

https://doi.org/10.1016/j.sbspro.2014.07.034

Martí-Parreño, J., Seguí-Mas, D., \& Seguí-Mas, E. (2016). Teachers' attitude towards and actual use of gamification. Procedia - Social and Behavioral Sciences, 228, 682-688.

https://doi.org/10.1016/j.sbspro.2016.07.104

Mora, A., Riera, D., González, C., \& Arnedo-Moreno, J. (2017). Gamification: a systematic review of design frameworks. Journal of Computing in Higher Education, 29(3), 516-548. https://doi.org/10.1007/s12528-017-9150-4

Morford, Z. H., Witts, B. N., Killingsworth, K. J., \& Alavosius, M. P. (2014). Gamification: The intersection between behavior analysis and game design technologies. Behavior Analyst, 37(1), 25-40. https://doi.org/10.1007/s40614-014-0006-1

Moro, S., Ramos, P., Esmerado, J., Jalali, S. M. J. (2019). Can we trace back hotel online reviews' characteristics using gamification features? International Journal of Information Management, 44, 88-95.

https://doi.org/10.1016/j.ijinfomgt.2018.09.015

Narayanan, D., Gertner-Samet, A., Malter Cohen, M., \& Polli, F. (2016). Gamification of the hiring process. Workforce Solutions Review, 32-34.

Nour, M. M., Rouf, A. S., \& Allman-Farinelli, M. (2018). Exploring young adult perspectives on the use of gamification and social media in a smartphone platform for improving vegetable intake. Appetite, 120, 547-556.

https://doi.org/10.1016/j.appet.2017.10.016

Osterwalder, A., \& Pigneur, Y. (2003, September). Modeling value propositions in e-Business. In Proceedings of the 5th International Conference on Electronic commerce (pp. 429-436). ACM. https://doi.org/10.1145/948005.948061

Park, J., Liu, D., Mun, Y. Y., \& Santhanam, R. (2019). GAMESIT: A gamified system for information technology training. Computers \& Education, 142, 103643. https://doi.org/10.1016/j.compedu.2019.103643

Pedreira, O., García, F., Brisaboa, N., \& Piattini, M. (2015). Gamification in software engineering - A systematic mapping. Information and Software Technology, 57, 157-168. https://doi.org/10.1016/j.infsof.2014.08.007

Perryer, C., Celestine, N. A., Scott-Ladd, B., \& Leighton, C. (2016). Enhancing workplace motivation through gamification: Transferrable lessons from pedagogy. The International Journal of Management Education, 14(3), 327-335. https://doi.org/10.1016/j.ijme.2016.07.001

Petersen, K., Feldt, R., Mujtaba, S., \& Mattsson, M. (2008). Systematic mapping studies in software engineering. 12th International Conference on Evaluation and Assessment in Software Engineering, 17, 10.

https://doi.org/10.1142/S0218194007003112

Poncin, I., Garnier, M., Mimoun, M. S. B., \& Leclercq, T. (2017). Smart technologies and shopping experience: Are gamification interfaces effective? The case of the Smartstore. Technological Forecasting and Social Change, 124, 320-331. https://doi.org/10.1016/j.techfore.2017.01.025 
Rauch, M. (2013). Best practices for using enterprise gamification to engage employees and customers. In International Conference on Human-Computer Interaction (pp. 276-283). Springer. https://doi.org/10.1007/978-3-642-39262-7_31

Robson, K., Plangger, K., Kietzmann, J. H., McCarthy, I., \& Pitt, L. (2016). Game on: engaging customers and employees through gamification. Business Horizons, 59(1), 29-36. https://doi.org/10.1016/j.bushor.2015.08.002

Rodrigues, L. F., Costa, C. J., \& Oliveira, A. (2016a). Gamification: A framework for designing software in e-banking. Computers in Human Behavior, 62, 620-634. https://doi.org/10.1016/j.chb.2016.04.035

Rodrigues, L. F., Oliveira, A., \& Costa, C. J. (2016b). Playing seriously - How gamification and social cues influence bank customers to use gamified e-business applications. Computers in Human Behavior, 63, 392-407. https://doi.org/10.1016/j.chb.2016.05.063

Rodrigues, L. F., Oliveira, A., \& Costa, C. J. (2016c). Does easeof-use contributes to the perception of enjoyment? A case of gamification in e-banking. Computers in Human Behavior, 61, 114-126. https://doi.org/10.1016/j.chb.2016.03.015

Roth, S., Schneckenberg, D., \& Tsai, C. W. (2015). The ludic drive as innovation driver: Introduction to the gamification of innovation. Creativity and Innovation Management, 24(2), 300-306. https://doi.org/10.1111/caim.12124

Routledge, H. (2016). Why games are good for business: how to leverage the power of serious games, gamification and simulations. Springer. https://doi.org/10.1057/9781137448989

Sigala, M. (2015). The application and impact of gamification funware on trip planning and experiences: the case of TripAdvisor's funware'. Electronic Markets, 25(3), 189-209. https://doi.org/10.1007/s12525-014-0179-1

Sillaots, M. (2014). Gamification of higher education by the example of course of research methods. Lecture Notes in Computer Science (including subseries Lecture Notes in Artificial Intelligence and Lecture Notes in Bioinformatics) (Vol. 8613 LNCS). https://doi.org/10.1007/978-3-319-09635-3_11
Sox, C. B., Kline, S. F., \& Crews, T. B. (2014). Identifying best practices, opportunities and barriers in meeting planning for Generation Y. International Journal of Hospitality Management, 36, 244-254. https://doi.org/10.1016/j.ijhm.2013.09.009

Stanculescu, L. C., Bozzon, A., Sips, R. J., \& Houben, G. J. (2016). Work and play: An experiment in enterprise gamification. Proceedings of the 19th ACM Conference on Computer-Supported Cooperative Work \& Social Computing (pp. 346-358). ACM. https://doi.org/10.1145/2818048.2820061

Suh, A., Cheung, C. M., Ahuja, M., \& Wagner, C. (2017). Gamification in the workplace: The central role of the aesthetic experience. Journal of Management Information Systems, 34(1), 268-305. https://doi.org/10.1080/07421222.2017.1297642

Terrill, B. (2008). My coverage of lobby [sic] of the social gaming summit. http://www.bretterrill.com/2008/06/my-coverage-oflobby-of- social-gaming.html

Werbach, K., \& Hunter, D. (2012). For the Win: How game thinking can revolutionize your business. Wharton Digital Press.

Xi, N., \& Hamari, J. (2019). Does gamification satisfy needs? A study on the relationship between gamification features and intrinsic need satisfaction. International Journal of Information Management, 46(November 2018), 210-221. https://doi.org/10.1016/j.ijinfomgt.2018.12.002

Xi, W., Gong, H., \& Wang, Q. (2019). How hand gestures influence the enjoyment in gamified mobile marketing. International Journal of Human Computer Studies, 127(September 2017), 169-180. https://doi.org/10.1016/j.ijhcs.2018.09.010

Yang, Y., Asaad, Y., \& Dwivedi, Y. (2017). Examining the impact of gamification on intention of engagement and brand attitude in the marketing context. Computers in Human Behavior, 73, 459-469. https://doi.org/10.1016/j.chb.2017.03.066

Yildirim, I. (2017). The effects of gamification-based teaching practices on student achievement and students' attitudes toward lessons. The Internet and Higher Education, 33, 86-92. https://doi.org/10.1016/j.iheduc.2017.02.002 